\title{
An Updated International Survey of Computer Models for Fire and Smoke
}

\author{
Stephen M. Olenick* And Douglas J. CARPenter \\ Combustion Science \& Engineering, Inc. \\ Columbia, MD 21045, USA
}

\begin{abstract}
In 1992, a comprehensive survey of computer models for fire and smoke was conducted at the request of the Forum for International Cooperation on Fire Research. This study serves as an update to that work. One hundred sixty eight computer modeling programs for fire and smoke from several countries were identified and categorized. The developers were contacted and given an opportunity to supply information about their particular model via an electronic survey. The results of the survey will be made available on the internet at www.firemodelsurvey. com. A discussion of the categories of computer fire models is included, followed by lists of the identified models.
\end{abstract}

KEY WORDS: modeling, computer fire models, model survey, model database, computational fluid dynamics, CFD.

\section{INTRODUCTION}

T N 1992, FRIEDMAN [1] conducted a survey of computer fire models for the Forum for International Cooperation on Fire Research. This survey was widely published and offered a source of information on many computer fire models. The original survey work identified 74 computer-modeling programs, and outlined their use in the fire engineering profession.

In the ten years since the original survey paper was published, computer modeling of fire and smoke transport has become a more accepted practice. Increased use of computer modeling is due to a greater database of fire knowledge that has become available in the last ten years from research and

\footnotetext{
*Author to whom corresponding should be addressed. E-mail: solenick@csefire.com

Journal of Fire Protection Engineering, Vol. 13-May 2003 
experimentation as well as from more-sophisticated computer resources allowing for improved and faster computation methods to be employed. This increased use of modeling is also attributable to the move towards performance-based building codes in the United States and other countries. Instead of using a prescriptive building code, engineers now can design for egress of building occupants in unique geometries under varying fire conditions.

Due to the growth in the use of computer modeling, most of the computer programs listed in the original survey have been updated in the last 10 years. Furthermore, numerous new models have been developed. Hence, an updated list of available computer models for fire and smoke transport is warranted. The goals of this project were to:

(1) Update the survey information of the models identified in the original survey.

(2) Identify and survey new models developed since the original survey.

(3) Include supplementary information about the models including contact information, availability, price, and additional references in response to a letter to the editor suggestion [135].

(4) Provide a logical categorization of computer modeling programs, and include a description of each category.

(5) Post the full, categorized results of the model survey on the Internet, allowing access of these results to the entire engineering community.

(6) Create a mechanism to update the survey periodically. This will allow ample time for model development, while not allowing the database to become outdated.

The categories chosen for computer fire models include zone models, field models, detector response, fire endurance, egress, and miscellaneous. The miscellaneous category includes models that have characteristics covering several of the categories, making it difficult to be placed in a single category, or models that have unique capabilities which do not allow them to be categorized anywhere else. These categories are similar to those in the original survey [1] and to those outlined by Hunt [2], who provides a general description of each category.

\section{THE SURVEY}

While the original survey was intended to provide basic information about each model, this new survey is intended to provide a comprehensive index of models, and reference information for the model descriptions and background. The survey is not intended to be the sole informational source for a particular model, but instead will provide enough information so that 
readers can decide if a model may meet their needs. Then, readers can review the references listed or contact the developer to obtain more detailed information.

The original survey of computer fire models [1] provided the following information:

(a) Model name

(b) Short description

(c) Modelers, Organizations

(d) References

(e) Availability

(f) Hardware

(g) Language

(h) Size

(i) Detailed description

This information provided a logical presentation of capabilities and critical data on each computer model. The current survey is modeled after Friedman [1], with some changes and additions:

(1) The version number of the model is to be given. The reader will then know to what version the survey refers and whether the reader is working with an older or more recent version of the model.

(2) A classification is provided as part of the model survey (i.e., zone model, field model, etc.)

(3) Three types of references are requested: user's guide, technical references, and validation references.

(4) The cost of purchasing the model is to be given. While many models may be available, it is essential to know if the model is affordable, as well as if special prices are available for students or researchers.

(5) Contact information for the developer, or person in charge of maintaining the model is requested. The contact information provides the user a point of contact for further information.

A survey form encompassing all of the original and new information elements was then developed. Appendix A is a sample completed survey form for the NIST zone model FAST/CFAST. Complete results from the survey are available only on the internet at www.firemodelsurvey.com. In a number of cases, no updated survey information was obtained. This introduced gaps of information on some models in the database. When possible, these gaps were filled by using the original survey data. It is the intent of the authors to maintain and update this database. Hence, as other model surveys are submitted, they will be included in future updates. 


\section{THE MODELS}

Before the model survey was created, the fire engineering community was polled to identify computer models for fire and smoke. The models identified by the fire engineering community were combined with those listed in the original survey, as well as others found in assorted fire modeling literature to develop a complete list of known fire models. These models were then categorized, and a survey form was sent to developers or known points of contact to collect more information about each model.

Availability of a model was found to be an important area of interest in the engineering community. It was decided that all models should be included in the database even if the model is unavailable, outdated, or not maintained. The reason for inclusion of these models was that while newer, more sophisticated and better maintained models may be available, previous research work may involve older, now outdated and no longer maintained, and possibly unavailable models. The database with the inclusion of these models will provide researchers with a source that describes the characteristics of these older, no longer maintained, or unavailable models.

A description of the overall model identification and categorization is provided below:

\section{Zone Models}

A zone model is a computer program that predicts the effects of the development of a fire inside a relatively enclosed volume. In most applications, the volume is not totally enclosed as doors, windows, and vents are usually included in the calculation. Zone models for compartments have been developed for both single-room and multiroom configurations.

The 'zonal' approach theory to modeling plume and layer development in confined spaces was applied to fires by several groups in the 1970s, e.g. Zukoski [3]. The 'zonal' approach divides the area of interest into a number of uniform zones, that when combined, describe the area of interest as a whole [4]. Within each of these zones, the pertinent conservation laws (i.e. mass and energy), in the form of mathematical equations describing the conditions of interest, are solved [4]. The 'zonal' approach for an enclosure fire usually divides an enclosure into two distinct zones: the hot upper smoke layer and the lower layer of cooler air. The plume acts as an enthalpy pump between the lower layer and the hot upper smoke layer. In reality, depending on the room size and heat release rate of the fire, there is no perfectly defined 'interface' between the hot upper smoke layer and lower layer and the hot upper smoke layer is not an uniform temperature (as higher temperatures are observed closer to the fire and plume); however, the 
use of two uniform zones allows for reasonable approximations of the development of a fire in an enclosure under many conditions.

Since the original survey [1], only a few new zone models (approximately 20) have been identified. While many of the models identified in the original survey have been improved, the basic zonal approach has been studied thoroughly and, therefore, the opportunities to develop a novel zone model are limited.

Table 1 lists the zone models which have been identified for the model survey.

\section{Field Models}

Field models, like zone models, are used to model fire development inside a compartment or a series of compartments. While a zone model divides the compartment into two zones, and solves the conservation equations (i.e., mass, energy, and momentum) within these zones, a field model divides the compartment into a large number (on the order of thousands) of control volumes and solves the conservation equations inside each control volume. This allows for a more detailed solution compared to zone models. Because there are more than two uniform zones, a field model can be appropriate for more complex geometries where two zones do not accurately describe the fire phenomenon. They can also be used for fires outside of compartments, such as large outdoor fuel tank fires [136].

While field models provide very detailed solutions, they require detailed input information, and usually require more computing resources in order to model the fire. This can create a costly time delay in obtaining a solution while zone models usually provide a solution more quickly.

In this study, nearly twice as many field models were identified than that in the original survey. This trend of increasingly growing numbers of field models stems from improved computer hardware which allows for faster, more complex computational techniques.

Table 2 lists the field models which have been identified for the model survey.

\section{Detector Response Models}

Detector response models predict primarily the time to activation of an initiating device. While most of these models predict the response of a thermal detector, sprinkler, or fusible link to a fire-induced flow, a few calculate the response of a smoke detector.

Typically, these models utilize the zonal approach to calculate smoke and heat transport, but utilize submodels to determine the response of the 
Table 1. Identified zone models for compartments.

\begin{tabular}{|c|c|c|c|}
\hline Model & Country & $\begin{array}{l}\text { Identifying } \\
\text { Reference }\end{array}$ & Description \\
\hline ARGOS & DENMARK & [8] & Multicompartment zone model \\
\hline ASET & US & [9] & $\begin{array}{l}\text { One room zone model with no } \\
\text { ventilation }\end{array}$ \\
\hline ASET-B & US & [10] & ASET in Basic instead of Fortran \\
\hline BRANZFIRE & NEW ZEALAND & [11] & $\begin{array}{l}\text { Multiroom zone model, including } \\
\text { flame spread, multiple fires, and } \\
\text { mechanical ventilation }\end{array}$ \\
\hline BRI-2 & JAPAN/US & [12] & $\begin{array}{l}\text { Two-layer zone model for } \\
\text { multistory, multicompartment } \\
\text { smoke transport }\end{array}$ \\
\hline CALTECH & & [117] & Preflashover zone model \\
\hline CCFM.VENTS & US & {$[13]$} & $\begin{array}{l}\text { Multi-room zone model } \\
\text { with ventilation }\end{array}$ \\
\hline CFAST/FAST & US & [14] & $\begin{array}{l}\text { Zone model with a suite of } \\
\text { correlation programs-CFAST is } \\
\text { the solver, FAST is a front-end }\end{array}$ \\
\hline CFIRE-X & GERMANY & [15] & $\begin{array}{l}\text { Zone model for compartment fires, } \\
\text { particularly liquid hydrocarbon } \\
\text { pool fires }\end{array}$ \\
\hline $\mathrm{CiFi}$ & FRANCE & [16] & Multiroom zone model \\
\hline COMPBRN-III & US & [17] & Compartment zone model \\
\hline COMF2 & US & [18] & $\begin{array}{l}\text { Single room postflashover } \\
\text { compartment model }\end{array}$ \\
\hline DACFIR-3 & US & [44] & Zone model for an aircraft cabin \\
\hline DSLAYV & SWEDEN & [19] & Single compartment zone model \\
\hline FASTlite & US & {$[20]$} & Feature limited version of CFAST \\
\hline FFM & US & {$[116]$} & Preflashover zone model \\
\hline FIGARO-II & GERMANY & {$[21]$} & $\begin{array}{l}\text { Zone model for determining } \\
\text { untenability }\end{array}$ \\
\hline FIRAC & US & [22] & $\begin{array}{l}\text { Uses FIRIN, includes complex } \\
\text { vent systems }\end{array}$ \\
\hline FireMD & US & {$[121]$} & One room, two zone model \\
\hline FIREWIND & AUSTRALIA & [23] & $\begin{array}{l}\text { Multiroom zone model with } \\
\text { several smaller submodels } \\
\text { (update of FIRECALC) }\end{array}$ \\
\hline FIRIN & US & [24] & $\begin{array}{l}\text { Multiroom zone model with ducts, } \\
\text { fans, and filters }\end{array}$ \\
\hline FIRM & US & [118] & Two zone, single compartment model \\
\hline FIRST & US & {$[25]$} & $\begin{array}{l}\text { One room zone model, includes } \\
\text { ventilation }\end{array}$ \\
\hline FMD & US & [26] & Zone fire model for atria \\
\hline HarvardMarkVI & US & [27] & Earlier version of FIRST \\
\hline HEMFAST & US & {$[28]$} & Furniture fire in a room \\
\hline HYSLAV & SWEDEN & [113] & Preflashover zone model \\
\hline
\end{tabular}


Table 1. Continued.

\begin{tabular}{|c|c|c|c|}
\hline Model & Country & $\begin{array}{l}\text { Identifying } \\
\text { Reference }\end{array}$ & Description \\
\hline IMFE & POLAND & [29] & $\begin{array}{l}\text { Single compartment zone model } \\
\text { with vents }\end{array}$ \\
\hline MAGIC & FRANCE & [30] & $\begin{array}{l}\text { Two-zone model for nuclear power } \\
\text { stations }\end{array}$ \\
\hline MRFC & GERMANY & [31] & $\begin{array}{l}\text { Multiroom zone model for } \\
\text { calculation of smoke movement } \\
\text { and temperature load on structures }\end{array}$ \\
\hline NAT & FRANCE & [32] & $\begin{array}{l}\text { Single compartment zone model with } \\
\text { attention to response of structures }\end{array}$ \\
\hline NBS & US & {$[112]$} & Preflashover zone model \\
\hline NRCC1 & CANADA & [33] & Single compartment zone model \\
\hline NRCC2 & CANADA & [34] & Large office space zone model \\
\hline OSU & US & [35] & Single compartment zone model \\
\hline Ozone & BELGIUM & [36] & $\begin{array}{l}\text { Zone model with attention to } \\
\text { response of structures }\end{array}$ \\
\hline POGAR & RUSSIA & [37] & Single compartment zone model \\
\hline RADISM & UK & [38] & $\begin{array}{l}\text { Zone model incorporating an } \\
\text { immersed ceiling jet within the } \\
\text { buoyant layer, sprinklers, and vents }\end{array}$ \\
\hline RFIRES & US & [115] & Preflashover zone model \\
\hline R-VENT & NORWAY & [39] & $\begin{array}{l}\text { Single room smoke ventilation } \\
\text { zone model }\end{array}$ \\
\hline SFIRE-4 & SWEDEN & {$[40]$} & Postflashover zone model \\
\hline SICOM & FRANCE & {$[41]$} & Single compartment zone model \\
\hline SMKFLW & JAPAN & [42] & $\begin{array}{l}\text { One-layer zone model for smoke } \\
\text { transport in buildings }\end{array}$ \\
\hline SmokePro & AUSTRALIA & [122] & $\begin{array}{l}\text { Single compartment smoke layer } \\
\text { interface position zone model }\end{array}$ \\
\hline SP & UK & {$[114]$} & Preflashover zone model \\
\hline WPI-2 & US & {$[43]$} & Single compartment zone model \\
\hline WPIFIRE & US & {$[124]$} & Mufti-room zone model \\
\hline ZMFE & POLAND & [29] & Single compartment zone model \\
\hline
\end{tabular}

These models have been identified by the authors, but no references or survey information was provided: CISNV (Russia), Firepro (UK), FLAMES (France).

thermal elements in the detectors to the heat and flow field. The inputs to the submodels are usually the characteristics of the thermal element (such as RTI and activation temperature), location of the thermal element, and the heat release rate of the fire. For some of the more sophisticated detection zone models, details such as compartment geometry and building material characteristics are required.

The model then uses simplified modeling of the fire and calculates the heat transfer at the thermal element to determine the time to activation. 
Table 2. Identified field models.

\begin{tabular}{|c|c|c|c|}
\hline Model & Country & $\begin{array}{l}\text { Identifying } \\
\text { Reference }\end{array}$ & Description \\
\hline ALOFT-FT & US & [45] & $\begin{array}{l}\text { Smoke movement from large } \\
\text { outdoor fires }\end{array}$ \\
\hline CFX & UK & {$[46]$} & $\begin{array}{l}\text { General purpose CFD software, } \\
\text { applicable to fire and explosions }\end{array}$ \\
\hline FDS & US & [47] & $\begin{array}{l}\text { Low Mach number CFD code } \\
\text { specific to fire-related flows }\end{array}$ \\
\hline FIRE & AUSTRALIA & [48] & $\begin{array}{l}\text { CFD model with water sprays } \\
\text { and coupled to solid/liquid phase } \\
\text { fuel to predict burning rate and } \\
\text { extinguishment }\end{array}$ \\
\hline FLUENT & US & [133] & General purpose CFD software \\
\hline JASMINE & UK & {$[49]$} & $\begin{array}{l}\text { Field model for predicting } \\
\text { consequences of fire to evaluate } \\
\text { design issues (based on } \\
\text { PHOENICS) }\end{array}$ \\
\hline KAMELEON FireEx & NORWAY & {$[50]$} & $\begin{array}{l}\text { CFD model for fire linked to a } \\
\text { finite element code for thermal } \\
\text { response of structures }\end{array}$ \\
\hline KOBRA-3D & GERMANY & {$[51]$} & $\begin{array}{l}\text { CFD for smoke spread and heat } \\
\text { transfer in complex geometries }\end{array}$ \\
\hline MEFE & PORTUGAL & [52] & $\begin{array}{l}\text { CFD model for one or two } \\
\text { compartments, includes } \\
\text { time-response of thermocouples }\end{array}$ \\
\hline PHOENICS & UK & [53] & Multipurpose CFD code \\
\hline RMFIRE & CANADA & {$[54]$} & $\begin{array}{l}\text { Two-dimensional field model for } \\
\text { the transient calculation of smoke } \\
\text { movement in room fires }\end{array}$ \\
\hline SMARTFIRE & UK & [55] & Fire field model \\
\hline SOFIE & UK/SWEDEN & [56] & Fire field model \\
\hline SOLVENT & US & {$[125]$} & $\begin{array}{l}\text { CFD model for smoke and heat } \\
\text { transport in a tunnel }\end{array}$ \\
\hline SPLASH & UK & [57] & $\begin{array}{l}\text { Field model describing interaction } \\
\text { of sprinkler sprays with fire gases }\end{array}$ \\
\hline STAR-CD & UK & [58] & General purpose CFD software \\
\hline UNDSAFE & US/JAPAN & {$[59]$} & $\begin{array}{l}\text { Fire field model for use in open } \\
\text { spaces, or in enclosures }\end{array}$ \\
\hline
\end{tabular}

These models have been identified by the authors, but no references or survey information was provided: FLOTRAN (US), STREAM (Japan), VESTA (France).

Care should be taken in selecting the proper model as some are valid only for flat ceilings, while others are valid only for unconfined ceilings. These factors limit the applicability of each model.

Since the original survey [1], a few new detection models have been developed. There also have not been many improvements in the detection models 
Table 3. Identified detector response models.

\begin{tabular}{|c|c|c|c|}
\hline Model & Country & $\begin{array}{l}\text { Identifying } \\
\text { Reference }\end{array}$ & Description \\
\hline DETACT-QS & US & [78] & $\begin{array}{l}\text { Calculates thermal detector activation } \\
\text { time under unconfined ceilings, } \\
\text { arbitrary fire }\end{array}$ \\
\hline DETACT-T2 & US & [79] & $\begin{array}{l}\text { Calculates thermal detector activation } \\
\text { time under unconfined ceilings, } t^{2} \text { fire }\end{array}$ \\
\hline G-JET & NORWAY & {$[80]$} & Smoke detection model \\
\hline JET & US & [81] & $\begin{array}{l}\text { Zone model with particular attention to } \\
\text { fusible links of sprinklers and vents }\end{array}$ \\
\hline LAVENT & US & [82] & $\begin{array}{l}\text { Zone model with particular attention to } \\
\text { fusible links of sprinklers and vents }\end{array}$ \\
\hline PALDET & FINLAND & [83] & $\begin{array}{l}\text { Response of sprinklers and fire detectors } \\
\text { under an unconfined ceiling }\end{array}$ \\
\hline SPRINK & US & [123] & Sprinkler response for high-rack storage fires \\
\hline TDISX & US & [84] & Warehouse sprinkler response \\
\hline
\end{tabular}

These models have been identified by the authors, but no references or survey information was provided: HAD (US).

identified in the original survey. This trend is due to the fact that detector response, particularly thermal detector response, is a well-known phenomenon that is already modeled fairly accurately by the current models. A growing number of field models also allow for smoke and thermal detection.

Table 3 lists the detector response models identified for the survey.

\section{Egress Models}

Egress models predict the time for occupants of a structure to evacuate. A number of egress models are linked to zone models, which will determine the time to the onset of untenable conditions in a building, but there are also stand-alone versions available. Egress models are often used in performance-based design analyses for alternative design code compliance and for determining where congestion areas will develop during egress.

Many of these models are quite sophisticated, offering unique computational methods, as well as interesting features including the psychological effects of fire on occupants due to the effect of smoke toxicity and decreasing visibility [5,6]. Many of these models also have useful graphical features so the movement of people in a building can be visualized during a simulation.

Approximately four times as many egress models have been identified in this work than were identified in the original survey [1]. This trend is again due to the fact that improved computer resources allow egress models to be created for more complex geometries involving the movement of larger 
groups of people. This trend is also due to the move that has been made or is being made towards performance-based design of buildings and therefore the evacuation of occupants through unique geometries and varying fire scenarios must be considered.

Table 4 lists the egress models which have been identified for the model survey.

Table 4. Identified egress models.

\begin{tabular}{|c|c|c|c|}
\hline Model & Country & $\begin{array}{l}\text { Identifying } \\
\text { Reference }\end{array}$ & Description \\
\hline Allsafe & NORWAY & {$[101]$} & Egress model including human factors \\
\hline ASERI & GERMANY & [102] & $\begin{array}{l}\text { Movement of people in complex } \\
\text { geometries, including behavioral } \\
\text { response to smoke and fire spread }\end{array}$ \\
\hline buildingEXODUS & UK & [6] & $\begin{array}{l}\text { Evacuation model that includes } \\
\text { interactions for thousands of people } \\
\text { in large geometries }\end{array}$ \\
\hline EESCAPE & AUSTRALIA & {$[103]$} & $\begin{array}{l}\text { Evacuation of multistory buildings } \\
\text { via staircases }\end{array}$ \\
\hline EGRESS & UK & [104] & $\begin{array}{l}\text { Cellular automata evacuation of } \\
\text { multiple people through complex } \\
\text { geometries. Includes visualization }\end{array}$ \\
\hline EgressPro & AUSTRALIA & [122] & $\begin{array}{l}\text { Egress program that includes coping } \\
\text { times and sprinkler-detector } \\
\text { activations }\end{array}$ \\
\hline ELVAC & US & {$[105]$} & $\begin{array}{l}\text { Egress program for use of elevators } \\
\text { for evacuation }\end{array}$ \\
\hline EVACNET 4 & US & [106] & $\begin{array}{l}\text { Determines optimal building } \\
\text { evacuation plan }\end{array}$ \\
\hline EVACS & JAPAN & {$[107]$} & $\begin{array}{l}\text { Evacuation model for determining } \\
\text { optimal design }\end{array}$ \\
\hline EXIT89 & US & [108] & Evacuation from a high-rise building \\
\hline EXITT & US & {$[5]$} & $\begin{array}{l}\text { Node and arc type egress model } \\
\text { with people behavior included }\end{array}$ \\
\hline PATHFINDER & US & [129] & Egress model \\
\hline SEVE-P & FRANCE & [109] & $\begin{array}{l}\text { Egress model with graphical output } \\
\text { that includes obstructions }\end{array}$ \\
\hline Simulex & UK & {$[110]$} & $\begin{array}{l}\text { Coordinate-based egress model } \\
\text { which models evacuation in } \\
\text { multistory buildings }\end{array}$ \\
\hline STEPS & UK & {$[130]$} & Egress model \\
\hline WAYOUT & AUSTRALIA & [111] & $\begin{array}{l}\text { Egress part of the FireWind suite } \\
\text { of programs }\end{array}$ \\
\hline
\end{tabular}

These models have been identified by the authors, but no references or survey information was provided: BFIRE II, BGRAF, ERM, ESCAPE, Magnetic Simulation, PEDROUTE, Takahashi's Fluid Model, VEGAS (UK). 


\section{Fire Endurance Models}

Fire endurance models simulate the response of building structural elements to fire exposure. Some of these models are stand-alone, while others are incorporated into zone or field models. The concept of fire endurance models is the same as that of the field models. The structural object is divided into smaller volumes, and the equations for thermal heat transfer and mechanical behavior for solids are solved to determine when the structure will fail. Typically, the material properties are required input for the model as well as the boundary conditions (i.e., the fire exposure) for the structural element.

These models can be very useful for determining when a beam or column will deform or fail, and for solving for a temperature versus time curve at a certain depth inside the structural element. Since many structural elements are constructed differently, have different features, and have different practical applications, care must be used in selecting a model that properly characterizes the structural element.

The number of fire endurance models identified in this survey has increased by a factor of two as compared to the earlier survey [1]. This trend is again due to improved computer resources, allowing more complete and complex finite element calculations to be conducted on structural elements. Also, the trend towards performance-based design has led to more model creation for structural elements.

Table 5 lists the fire endurance models identified for the model survey.

\section{Miscellaneous Models}

The models which are not appropriate for one of the previous categories or have features which fulfill more than one of the other categories have been termed miscellaneous. Many of these models are computer programs which contain many submodels and therefore can be used for several of the categories listed above. These are suites of programs which have several separate models which each address an individual aspect of fire and are contained in one computer package. Others are programs which model unique aspects of fires such as radiation or risk.

The number of these types of fire modeling programs has also increased substantially since the earlier survey was compiled. The models in this category can address such a wide variety of fire engineering subjects that their growth possibility is endless.

Table 6 lists the models termed miscellaneous identified for the model survey. 
Table 5. Identified fire endurance models.

\begin{tabular}{|c|c|c|c|}
\hline Model & Country & $\begin{array}{l}\text { Identifying } \\
\text { Reference }\end{array}$ & Description \\
\hline CEFICOSS & BELGIUM & [132] & Fire resistance model \\
\hline CIRCON & CANADA & {$[85]$} & $\begin{array}{l}\text { Fire resistance of loaded, reinforced } \\
\text { concrete columns with a circular } \\
\text { cross section }\end{array}$ \\
\hline CMPST & FRANCE & {$[127]$} & $\begin{array}{l}\text { Mechanical resistance of sections at } \\
\text { elevated temperatures }\end{array}$ \\
\hline COFIL & CANADA & {$[86]$} & $\begin{array}{l}\text { Fire resistance of loaded circular hollow } \\
\text { steel columns filled with plain concrete }\end{array}$ \\
\hline COMPSL & CANADA & {$[87]$} & $\begin{array}{l}\text { Temperatures of multilayer slabs during } \\
\text { exposure to fire }\end{array}$ \\
\hline FIRES-T3 & US & [88] & $\begin{array}{l}\text { Finite element heat transfer for } 1-, 2-\text {, } \\
\text { or 3-D conduction }\end{array}$ \\
\hline HSLAB & SWEDEN & [89] & $\begin{array}{l}\text { Transient temperature development in a } \\
\text { heated slab composed of one or } \\
\text { several materials }\end{array}$ \\
\hline INSTAI & CANADA & {$[90]$} & $\begin{array}{l}\text { Fire resistance of insulated, circular } \\
\text { hollow steel columns }\end{array}$ \\
\hline INSTCO & CANADA & {$[90]$} & $\begin{array}{l}\text { Fire resistance of insulated, circular } \\
\text { concrete-filled tubular steel columns }\end{array}$ \\
\hline LENAS & FRANCE & {$[127]$} & $\begin{array}{l}\text { Mechanical behavior of steel structures } \\
\text { exposed to fire }\end{array}$ \\
\hline RCCON & CANADA & {$[91]$} & $\begin{array}{l}\text { Fire resistance of loaded reinforced } \\
\text { concrete columns with rectangular } \\
\text { cross sections }\end{array}$ \\
\hline RECTST & CANADA & [92] & $\begin{array}{l}\text { Fire resistance of insulated rectangular } \\
\text { steel columns }\end{array}$ \\
\hline SAFIR & BELGIUM & [93] & $\begin{array}{l}\text { Transient and mechanical analysis of } \\
\text { structures exposed to fire }\end{array}$ \\
\hline SAWTEF & US & {$[94]$} & $\begin{array}{l}\text { Structural analysis of metal-plate } \\
\text { connected wood trusses exposed to fire }\end{array}$ \\
\hline SISMEF & FRANCE & {$[127]$} & $\begin{array}{l}\text { Mechanical behavior of steel and } \\
\text { concrete composite structures } \\
\text { exposed to fire }\end{array}$ \\
\hline SQCON & CANADA & [95] & $\begin{array}{l}\text { Fire resistance of square reinforced } \\
\text { concrete columns }\end{array}$ \\
\hline STA & UK & {$[126]$} & $\begin{array}{l}\text { Transient conduction in heated solid } \\
\text { objects }\end{array}$ \\
\hline TASEF & SWEDEN & [96] & $\begin{array}{l}\text { Finite element method for temperature } \\
\text { analysis of structures exposed to fire }\end{array}$ \\
\hline TCSLBM & CANADA & [97] & $\begin{array}{l}\text { Two dimensional temperature } \\
\text { distributions for fire-exposed concrete } \\
\text { slab/beam assemblies }\end{array}$ \\
\hline THELMA & UK & [98] & $\begin{array}{l}\text { Finite-element code for thermal analysis } \\
\text { of building components in fire }\end{array}$ \\
\hline
\end{tabular}


Table 5. Continued.

\begin{tabular}{|c|c|c|c|}
\hline Model & Country & $\begin{array}{l}\text { Identifying } \\
\text { Reference }\end{array}$ & Description \\
\hline TR8 & NEW ZEALAND & [99] & $\begin{array}{l}\text { Fire resistance of concrete slabs and } \\
\text { floor systems }\end{array}$ \\
\hline WSHAPS & CANADA & {$[100]$} & $\begin{array}{l}\text { Fire resistance of loaded, protected } \\
\text { W-shape steel columns }\end{array}$ \\
\hline
\end{tabular}

These models have been identified by the authors, but no references or survey information was provided: ABAQUS (US), ALGOR (US), ANSYS (US), COSMOS/M (US), FASBUS, LUSAS (UK), NASTRAN (US), TAS (US), VULCAN (UK), WALL2D (Canada).

Table 6. Identified miscellaneous models.

\begin{tabular}{|c|c|c|c|}
\hline Model & Country & $\begin{array}{l}\text { Identifying } \\
\text { Reference }\end{array}$ & Description \\
\hline ALARM & US & {$[60]$} & $\begin{array}{l}\text { Economic optimization of code } \\
\text { compliance measures }\end{array}$ \\
\hline ASCOS & US & {$[61]$} & Network air flow analysis \\
\hline ASKFRS & UK & {$[134]$} & $\begin{array}{l}\text { Suite of models including a } \\
\text { zone model }\end{array}$ \\
\hline ASMET & US & [62] & $\begin{array}{l}\text { Package of engineering tools for } \\
\text { analysis of atria smoke management }\end{array}$ \\
\hline BREAK1 & US & [119] & $\begin{array}{l}\text { Window response to fire } \\
\text { (glass breakage) }\end{array}$ \\
\hline Brilliant & NORWAY & [128] & $\begin{array}{l}\text { CFD model combined with analytical } \\
\text { models }\end{array}$ \\
\hline CONTAMW & US & [63] & Airflow model \\
\hline CRISP & UK & [64] & $\begin{array}{l}\text { Fire zone model with egress and } \\
\text { risk assessment }\end{array}$ \\
\hline FIERAsystem & CANADA & {$[65]$} & $\begin{array}{l}\text { Risk assessment model that includes } \\
\text { a suite of correlations }\end{array}$ \\
\hline FireCad & US & [129] & Front end for CFAST \\
\hline FiRECAM & CANADA & {$[66]$} & Risk damage assessment \\
\hline FIRESYS & NEW ZEALAND & [131] & $\begin{array}{l}\text { Suite of programs for designers } \\
\text { working under performance-based } \\
\text { fire codes }\end{array}$ \\
\hline FireWalk & US & {$[67]$} & $\begin{array}{l}\text { Uses CFAST zone model with } \\
\text { improved visualization }\end{array}$ \\
\hline FIREX & GERMANY & [68] & $\begin{array}{l}\text { Simple zone models mixed with } \\
\text { empirical correlations }\end{array}$ \\
\hline FIVE & US & {$[120]$} & Fire induced vulnerability evaluation \\
\hline FPETOOL & US & [69] & $\begin{array}{l}\text { Suite of models and correlations } \\
\text { including the zone model fire simulator }\end{array}$ \\
\hline FRAME & BELGIUM & {$[70]$} & Fire risk assessment model \\
\hline FriskMD & US & {$[121]$} & $\begin{array}{l}\text { Risk-based version of zone } \\
\text { model FireMD }\end{array}$ \\
\hline
\end{tabular}


Table 6. Continued.

\begin{tabular}{|c|c|c|c|}
\hline Model & Country & $\begin{array}{l}\text { Identifying } \\
\text { Reference }\end{array}$ & Description \\
\hline HAZARD I & US & {$[5]$} & $\begin{array}{l}\text { Zone model with extensive egress } \\
\text { capabilities }\end{array}$ \\
\hline MFIRE & US & [71] & Mine ventilation systems \\
\hline RadPro & AUSTRALIA & [122] & Fire radiation intensity model \\
\hline RISK-COST & CANADA & [72] & $\begin{array}{l}\text { Computes the expected risk to } \\
\text { life and the fire cost expectation }\end{array}$ \\
\hline RiskPro & AUSTRALIA & [122] & Risk ranking model \\
\hline SMACS & US & [73] & $\begin{array}{l}\text { Smoke movement through } \\
\text { air-conditioning systems }\end{array}$ \\
\hline SMOKEVIEW & US & [74] & Visualization program for FDS \\
\hline SPREAD & US & [75] & $\begin{array}{l}\text { Predicts burning rate and spread } \\
\text { rate of a fire ignited on a wall } \\
\text { using data from bench-scale tests }\end{array}$ \\
\hline UFSG & US & [76] & $\begin{array}{l}\text { Predicts upward flame spread and } \\
\text { growth on non-charring and } \\
\text { charring materials }\end{array}$ \\
\hline WALLEX & CANADA & [77] & $\begin{array}{l}\text { Calculation of heat transfer from } \\
\text { window fire plume to wall } \\
\text { above window }\end{array}$ \\
\hline
\end{tabular}

These models have been identified by the authors, but no references or survey information was provided: COFRA (US), DOW Indices (US), FREM (Australia), Risiko (Switzerland).

\section{CONCLUSIONS AND FUTURE WORK}

The number of models identified by the fire engineering community has increased substantially over the last ten years. Of particular interest is the increase in available field and miscellaneous models. The field models are increasing in numbers and complexity due to increases in available computer resources, research, and practical knowledge. The miscellaneous models are increasing in numbers due to a greater, more accessible database of fire data. Therefore, computer fire modeling is moving in a trend to provide predictions that are more accurate, as well as predictions about fire phenomenon that previously no computer fire model addressed.

The database of survey results will be made available on the internet for free, at www.firemodelsurvey.com and will likely supplement another model survey being conducted currently by the International Council for Research and Innovation in Building and Construction (CIB) which is surveying models on building performance, including fire performance [7]. It is the hope of the authors that the developers will continue to utilize the survey as a means of providing information about their model to the fire engineering community. 


\section{ACKNOWLEDGMENTS}

The authors wish to thank all the developers and points of contact of the models for taking the time to describe their model in the survey. The authors also wish to thank the members of the fire engineering community who took the time to bring computer models to the attention of the authors. Finally, the authors wish to thank Vijay D'Souza for his help locating many of the references for the models.

\section{APPENDIX A}

\section{Sample Survey Form}

Model Name:

Version:

Classification:

Very Short Description:

Modeler(s),

Organization(s):

User's Guide:

Technical References:

Validation References:

\section{FAST/CFAST}

3.1.6

Zone Model

A zone model to predict the environment in a compartmented structure.

Walter W. Jones, National Institute of Standards and Technology.

A User's Guide for FAST: Engineering Tools for Estimating Fire Growth and Smoke Transport, NIST Special Publication 921, 2000 Edition.

A Technical Reference for CFAST: An Engineering Tools for Estimating Fire Growth and Smoke Transport, NIST Technical Note 1431.

(all of the following papers cite experimental comparisons with the model):

A Comparison of CFAST Predictions to USCG Real-Scale Fire Tests, Journal of Fire Protection Engineering (in press).

A Technical Reference for CFAST: An Engineering Tools for Estimating Fire Growth and Smoke Transport, NIST Technical Note 1431 (2000).

Quantifying fire model evaluation using functional analysis, Fire Safety Journal 33 (1999), 167-184. 
Development of an Algorithm to Predict Vertical Heat Transfer Through Ceiling/Floor Conduction, Fire Technology 34, 139 (1998).

Fire Hazard Assessment Methodology, NISTIR 5836 (1996).

Progress Report on Fire Modeling and Validation, NISTIR 5835 (1996).

Comparison of CFAST Predictions to Real Scale Fire Tests, Institut de Securite, Fire Safety Conference on Performance Based Concepts (1996).

Calculating Flame Spread on Horizontal and Vertical Surfaces, NISTIR 5392 (1994).

Modeling Smoke Movement Through

Compartmented Structures, Journal of Fire Sciences, 11, 172 (1993).

Improvement in Predicting Smoke Movement in Compartmented Structures, Fire Safety Journal, 21, 269 (1993).

Verification of a Model of Fire and Smoke Transport, Fire Safety Journal 21, 89 (1993).

Availability:

Price:

Necessary Hardware:

Computer Language:

Size:

Contact Information:
Available from http://fast.nist.gov/ or the National Fire Protection Association (http:// www.nfpa.org).

There is no cost from NIST for the download or having the CD; NFPA distributes the

$\mathrm{CD}$ together with printed documentation for $\$ 25$.

Intel architecture, running DOS 6.0 or later. Runs under Windows 3.1, 95, 98 and 2000, but not NT. Versions are available for the Silicon Graphics systems.

FORTRAN/C

Approximately $10 \mathrm{MB}$ of disk space, and $4 \mathrm{MB}$ of RAM required.

Walter W. Jones, 301-975-6887, wwj@nist.gov 
Detailed Description:

CFAST is the Consolidated Model of Fire Growth and Smoke Transport. It is the kernel of the zone fire models that are supported by BFRL. FAST and FASTLite are data editors and reporting tools which are "front" and "back" ends for the model CFAST. For additional details on the naming convention, please visit the web site http://fast.nist.gov/versionhistory.htm. There are a several data editors which have been developed elsewhere: FireCAD from the RJA Group and FireWalk through the University of California, Berkeley.

CFAST is a zone model and is used to calculate the evolving distribution of smoke, fire gases and heat throughout a constructed facility during a fire. In CFAST, each compartment is divided into two layers, and many zones for detailed interactions. The modeling equations used in CFAST take the mathematical form of an initial value problem for a system of ordinary differential equations (ODE). These equations are derived using the conservation of mass, the conservation of energy, the ideal gas law and relations for density and internal energy. These equations predict as functions of time quantities such as pressure, layer heights and temperatures given the accumulation of mass and enthalpy in the two layers. The CFAST model then solves of a set of ODEs to compute the environment in each compartment and a collection of algorithms to compute the mass and enthalpy source terms. The model incorporates the evolution of the species, such as carbon monoxide, which are important to the safety of individuals subjected to a fire environment.

Version 3.1.6 models up to 30 compartments, a fan and duct system for each compartment, 31 individual fires, up to one flame-spread object, multiple plumes and fires, multiple sprinklers and detectors, and the ten species considered most important in toxicity of fires including the effective fatal dose. The geometry includes variable area-height relations, ignition of multiple objects such as furniture, thermophysical and pyrolysis databases, multilayered walls, ignition through barriers and vents, wind, the stack effect, building leakage, and flow through holes in floor-ceiling connections. The distribution includes graphic and text report generators, a plotting package and a system for comparing many runs done for parameters

\section{REFERENCES}

1. Friedman, R., "An International Survey of Computer Models for Fire and Smoke," Journal of Fire Protection Engineering, Vol. 4, No. 3, 1992, pp. 81-92. 
2. Hunt, S., "Computer Fire Models," NFPA Update Section News, Vol. 1, No. 2, Oct./Nov., 2000 , pp. 7-9.

3. Zukoski, E. E., "Development of a Stratified Ceiling Layer in the Early Stages of a ClosedRoom Fire," Fire and Materials, Vol. 2, No. 2, 1978.

4. Cox, G. "Compartment Fire Modelling," Combustion Fundamentals of Fire, Academic Press, 1995, p. 334.

5. Bukowski, R. W., Peacock, R. D., Jones, W. W. and Forney, C. L., Technical Reference Guide for the HAZARD I Fire Hazard Assessment Method, Volume 2, NIST Handbook 146/II, National Institute of Standards and Technology, June 1991.

6. BuildingEXODUS V3.0 User Guide and Technical Manual, Doc Rev 3.0. University of Greenwich, May 2000.

7. CIB Program on Performance-Based Building http://www.cibprogram.dbce.csiro.au

8. Danish Institute of Fire Technology, ARGOS User's Guide, Datovej 48, DK 3460 Birkeroed, 1991.

9. Cooper, L. Y. and Stroup, D. W., Calculating Available Safe Egress Time (ASET) - A Computer Program and User's Guide, NBSIR 82-2578, National Bureau of Standards (now National Institute of Standards and Technology), 1982.

10. Walton, W. D., ASET-B: A Room Fire Program for Personal Computers, NBSIR 85-3144-1, National Bureau of Standards (now National Institute of Standards and Technology), 1985.

11. A User's Guide to BRANZFIRE Software, Building Research Association of New Zealand, 2000.

12. Nakamura, K. and Tanaka, T., "Predicting Capability of a Multiroom Fire Model," In: Proceedings of the Second International Symposium on Fire Safety Science, 1988.

13. Cooper, L. Y. and Forney, G. P., The Consolidated Compartment Fire Model (CCFM) Computer Code Application CCFM.VENTS, Part I, NISTIR 4342, National Institute of Standards and Technology, 1990.

14. Peacock, R. D., Reneke, P. A., Jones, W. W., Bukowski, R. W., Forney, G. P., A User's Guide for FAST: Engineering Tools for Estimating Fire Growth and Smoke Transport, NIST Special Publication 921, National Institute of Standards and Technology, 2000.

15. Offenhauser, F., Barth, U. and Schnatz, G., "CFIRE-X: Simulation of Extinguishing Methods Concerning Room Fires," VFDB, n. 1, 1991.

16. Bodart, X. and Curtat, M., CIFI Computer Code: Air and Smoke Movement During a Fire in a Building With Ventilation Ducts Networks Equipment, CIB Publication 104, CIB W14 Workshop on Fire Modeling, Berlin, West Germany, March 1987.

17. Ho, V., Siu, N. and Apostolakis, G., "COMPBRN III-A Fire Hazard Model for Risk Analysis," Fire Safety Journal, Vol. 13, No. 2-3, 1988.

18. Babrauskas, V., COMPF2 - A Program for Calculating Post-Flashover Fire Temperatures Final Report, NBS Tech Note 991, National Bureau of Standards (now National Institute of Standards and Technology), 1979.

19. A User's Guide for DSLAYV: Simulating Fires in Natural and Forced Ventilated Enclosures, FOA Report C20637, National Defense Research Institute, Sweden, 1986.

20. Portier, R. W., Peacock, R. D. and Reneke, P. A., FASTLite: Engineering Tools for Estimating Fire Growth and Smoke Transport, NIST Special Publication 899, National Institute of Standards and Technology, 1999.

21. Heins, T., "Simulation Model for the Safety Assessment of Spreading Smoke From Fires in Extended Enclosures," Dissertation, Technical University Braunschweig, 1991.

22. Nicholas, B. D. and Gregory, W. S., FIRAC User's Manual: A Computer Code to Simulate Fire Accidents in Nuclear Facilities, NUREG/CR-4561, LA-10678-M, Los Alamos National Lab, 1986.

23. Shestopal, V. O., "Computer Program for an Uninhibited Smoke Plume and Associated Computer Software," Fire Technology, Vol. 29, No. 3, 1993, pp. 246-267. 
24. Chan, M. K., Ballinger, M. Y., Owczarski, P. C. and Sutter, S. L., User's Manual for FIRIN 1: A Computer Code to Characterize Accidental Fire and Radioactive Source Terms in Nuclear Fuel Cycle Facilities, Battelle Pacific Northwest Lab Report PNL-4532, NUREG/CR-3037 (Dec. 1982), Also Claybrook, S. W. FIRIN Preprocessor User's Manual, Numerical Applications, Inc., Richland, WA 99352, November 1991.

25. Mitler, H. E. and Rockett, J. A., User's Guide to FIRST, A Comprehensive Single-Room Fire Model, NBSIR 87-3595, National Bureau of Standards (now National Institute of Standards and Technology), 1987.

26. Milke, J. A. and Mowrer, F. W., "A Design Algorithm for Smoke Management Systems in Atria and Covered Malls," Report FP 93-04, Report to the American Society of Heating, Refrigerating and Air-Conditioning Engineers (ASHRAE), University of Maryland, May 1993.

27. Rockett, J., Using the Harvard/National Institute of Standards and Technology Mark VI Fire Simulation, NISTIR 4464, National Institute of Standards and Technology, Gaithersburg, MD, November 1990.

28. Dietenberger, M. A., "Validated Furniture Fire Model with FAST (HEMFAST)," NISTGCR-89-564, National Institute of Standards and Technology, June 1989.

29. Personal communication with Rector Jerzy Wolanin, Warsaw, Jerzy.Wolanin@sgsp.edu.pl.

30. Gautier, B., Pages, O. and Thibert, E., "MAGIC: Global Modelling of Fire Into Compartments," In: Proceedings of the 8th Interflam Conference, Vol. 2, Edinburgh, Scotland, 1999.

31. Schneider, U., Lebeda, C. and Max, U., "An Evaluation and Applicability Study for Use of Different Fire Codes in NPP Fire Design," In: Proceedings of the Post Smirt Conference n. 6 , Lyon, France, August 1997.

32. Curtat, M. R., "NAT (NATural Fire Conditions)," CIB Publication 104, CIB W14 Workshop on Fire Modeling, Berlin, 1987.

33. Takeda, H. and Yung, D., "Simplified Fire Growth Models for Risk-Cost Assessment in Apartment Buildings," Journal of Fire Protection Engineering, Vol. 4, No. 2, 1992.

34. Personal communication with David Yung, Fire Risk Management Program, National Research Council of Canada, Ottawa, ON.

35. Sauer, J. M. and Smith, E. E., "Mathematical Model of a Ventilation-Controlled Compartment Fire," Journal of Fire Sciences, Vol. 1, 1983, pp. 235-254.

36. Competitive Steel Buildings through Natural Fire Safety Concept, Part 2: Natural Fire Models, Final Report, Profil ARBED, March 1999.

37. Astapenko, V., Koshmarov, Y., Molchadski, I. and Shevlyakov, A., Termogazodinami of Fires in the Rooms, Moscow, Stroiizdat, 1988 (from Higher Engineering Fire-Technical School, Moscow).

38. Persson, B. and Ingason, H., Modelling of Interaction Between Sprinklers and Fire Vents: Present Knowledge, Swedish National Testing Institute, SP REPORT 1996:32, Sweden, 1996.

39. Meland, O. and Skaret, E., “User's Manuel for RVENT," Report STF25 A91034, The Foundation for Scientific and Industrial Research at the Norwegian Institute of Technology (SINTEF), Trondheim, Norway, 1987.

40. Magnusson, S. E., and Thelandersson, S., Temperature-Time Curves of Complete Process of Fire Development, Theoretical Study of Wood Fuel Fires in Enclosed Spaces, APS CI 65, Department of Fire Safety Engineering, Lund University, Sweden, 1970.

41. Introductory Report of a Compartment Fire Simulation using a Two-Zone Model-June, 1999, Centre Technique Industriel de la Construction Metallqiue (CTICM), France.

42. Matsushita, T., Fukai, H. and Terai, T., "Calculation of Smoke Movement in Building in Case of Fire," In: Proceedings of the 1st International Symposium on Fire Safety Science, 1985. 
43. Satterfield, D. B. and Barnett, J. R., User's Guide to WPI-HARVARD Version 2 (WPI-2) A Compartment Fire Model, Worcester Polytechnic Institute, Center for Fire Safety Studies, Worcester, MA, August 1990.

44. MacArthur, C. D., Dayton Aircraft Fire Cabin Model, Version 3, U.S. Dept. of Transportation, Atlantic City, NJ, DOT/FAA. CT-81/69-I, June 1982.

45. McGrattan, K. B., Baum, H. R., Walton, W. D. and Trelles, J. J., Smoke Plume Trajectory from In Situ Burning of Crude Oil in Alaska - Field Experiments and Modeling of Complex Terrain, NISTIR 5958, National Institute of Standards and Technology, 1997.

46. CFX-5 User Manual, AEA Technology, Harwell, UK, 2000.

47. McGrattan K. B. and Forney, G. P., Fire Dynamics Simulator - User's Manual, NISTIR 6469, National Institute of Standards and Technology, 2000.

48. Novozhilov, V., Harvie, D. J. E., Green, A. R. and Kent, J. H., "A Computational Fluid Dynamic Model of Fire Burning Rate and Extinction by Water Sprinkler," Combustion Science and Technology, Vol. 123, No. 1-6, 1997, pp. 227-245.

49. Cox, G. and Kumar, S., "Field Modelling of Fire in Forced Ventilated Enclosures," Combustion Science and Technology, Vol. 52, No. 7, 1986.

50. Kameleon FireEx 99 User Manual, SINTEF Energy Research report TRF5119, Trondheim, Norway.

51. Schneider, V., WinKobra 4.6 - User's Guide, I.S.T. Intefrierte Sischerheits-Technik GmbH, Germany.

52. Viegas, J. C. G., Seguranca Contra Incendios Em Edificios. Modelacao Matematica De Incendios E Validacao Experimental (Fire Safety in Buildings, Mathematical Modelling of Fire and Experimental Validation), Lisbon, Portugal: Instituto Superior Tecnico, Ph.D. Thesis, 1999.

53. PHOENICS User's Guide, http://www.cham.co.uk/phoenics/d_polis/d_docs/tr326/ tr326top.htm.

54. Hadjisophocleous, G. V. and Yakan, A., Computer Modeling of Compartment Fires, Internal Report No. 613, Institute for Research in Construction, National Research Council of Canada, Ottawa, ON, 1991.

55. SMARTFIRE V2.0 User Guide and Technical Manual, Doc Rev 1.0, July 1998.

56. Rubini, P. A., "SOFIE - Simulation of Fires in Enclosures," In: Proceedings of the 5th International Symposium on Fire Safety Science, 1997.

57. Gardiner, A. J., The Mathematical Modeling of the Interaction Between Sprinkler Sprays and the Thermally Buoyant Layers of Gases from Fires, South Bank Polytechnic, PhD Thesis, 1998 (now Under Development by FRS)

58. Star-CD V3.100A User Guide, Computational Dynamics Ltd., http://www.cd.co.uk.

59. Yang, K. T. and Chang, L. C., UNDSAFE-1: A Computer Code for Buoyant Flow in an Enclosure, NBS GCR 77-84, National Bureau of Standards (now National Institute of Standards and Technology), 1977.

60. Weber, S. F. and Lippiatt, B. C., ALARM 1.0, Decision Support Software for CostEffective Compliance with Fire Safety Codes, NISTIR 5787, National Institute of Standards and Technology, 1996 (available from NFPA).

61. Klote, J. H. and Milke, J. A., Design of Smoke Management Systems. American Society of Heating, Refrigerating and Air-Conditioning Engineers (ASHRAE), 1992.

62. Klote, J. H., Method of Predicting Smoke Movement in Atria with Application to Smoke Management, NISTIR 5516, National Institute of Standards and Technology, 1994.

63. Dols, W. S., Walton, G. N. and Denton, K. R., CONTAMW 1.0 User Manual, Multizone Airflow and Contaminant Transport Analysis Software, NISTIR 6476, National Institute of Standards and Technology, 2000. 
64. Fraser-Mitchell, J. N. and Pigott, B. B., "Modelling Human Behaviour in the Fire Risk Assessment Model CRISP 2," In: Proceedings of the International Symposium CIB W14: Fire Safety Engineering, Part 3, p. 1, 1993.

65. Benichou, N., Kashef, A., Torvi, D.A., Hadjisophocleous, G.V. and Reid, I., "FIERAsystem: A Fire Risk Assessment Model for Light Industrial Building Fire Safety Evaluation," Research Report 120, Institute for Research in Construction, National Research Council of Canada, November, 2002.

66. Dutcher, C. R., Yung, D. T., and Hadjisophocleous, G. V., FiRECAM System Model Documentation, Internal Report 732, Institute for Research in Construction, National Research Council of Canada, Ottawa, ON, 1996.

67. Bukowski, R. and Sequin, C., "The FireWalk System: Fire Modeling in Interactive Virtual Environments," In: Proceedings of the 2nd International Conference on Fire Research and Engineering, Gaithersburg, MD, 1997.

68. Schneider, V., FIREX 2.2 - User's Guide. I.S.T. Intefrierte Sischerheits-Technik GmbH, Germany.

69. Nelson, H. E., FPETOOL User's Guide, NISTIR 4439, National Institute of Standards and Technology, 1990.

70. De Smet, E., FRAM: Handbook for the User of this Fire Risk Assessment Method for Engineering, 1999 Edition.

71. Chang, X., Laage, L. W. and Greuer, R. E., User's Manual for MFIRE: A Computer Simulation Program for Mine Ventilation and Fire Modeling, U.S. Bureau of Mines, I.C. 9254, 1990.

72. Beck, V. R. and Yung, D., "A Cost-Effective Risk Assessment Model for Evaluation Fire Safety and Protection in Canadian Apartment Buildings," In: Proceedings of the International Fire Protection Engineering Institute-V, Ottawa, Canada, 1989.

73. Klote, J. H., "A Computer Model of Smoke Movement by Air Conditioning Systems (SMACS)," Fire Technology, Vol. 24, 1988, pp. 299-311.

74. Forney, G. P. and McGrattan, K. B., User's Guide for Smokeview Version 1.0 - A Tool for Visualizing Fire Dynamics Simulation Data, NISTIR 6513, National Institute of Standards and Technology, 2000.

75. Mitler, H. E., "Predicting the Spread Rates of Fires on Vertical Surfaces," 23rd International Symposium on Combustion, The Combustion Institute, 1990.

76. Delichatsios, M. A., Chen, Y. and Motevalli, V., "Flame Spread on Charring Materials: Numerical Prediction of Experimental Results," In: Proceedings of the Fall Technical Meeting of the Eastern Section of the Combustion Institute, The Combustion Institute, 1991.

77. Oleszkiewicz, I., "Heat Transfer from a Window Fire Plume to a Building Facade," collected Papers in Heat Transfer - 1989, HTD - Vol. 123, American Society of Mechanical Engineers, pp. 163-170.

78. Evans, D. D. and Stroup, D. W., "Methods to Calculate the Response Time of Heat and Smoke Detectors Installed Below Large Unobstructed Ceilings," Fire Technology, Vol. 22, 1986, pp. 54-65.

79. Evans, D. D., Stroup, D. W., and Martin, P., Evaluating Thermal Fire Detection Systems (SI Units), NBS SP 713, National Bureau of Standards (now National Institute of Standards and Technology), 1986.

80. Jensen, G., Lonvik, T. and Heskestad, A. W., “Application Specific Sensitivity: A Simple Engineering Model to Predict Response of Installed Smoke Detectors," In: Proceedings of the 11th International Conference on Automatic Fire Detection " AUBE 1999," University of Duisburg, Germany, 1999.

81. Davis, W. D., The Zone Fire Model JET: A Model for the Prediction of Detector Activation and Gas Temperature in the Presence of a Smoke Layer, NISTIR 6324, National Institute of Standards and Technology, 1999. 
82. Davis, W. D. and Cooper, L.Y., Estimating the Environment and the Response of Sprinkler Links in Compartment Fires with Draft Curtains and Fusible Link-Actuated Ceiling Vents-Part II: User Guide for the Computer Code LAVENT, NBSIR 89-4122, National Bureau of Standards (now National Institute of Standards and Technology), 1989.

83. Bjorkman, J., Huttunen, O. and Kokkala, M., "Calculation Models for Fire Detectors," Research Notes 1036, Technical Research Centre of Finland.

84. Yu, H.-Z., A Sprinkler-Response-Prediction Computer Program for Warehouse Applications, FMRC Technical Report, J.I. OR2E1.RA, 1991.

85. Lie, T. T. and Celikkol, B., "Method to Calculate the Fire Resistance of Circular Reinforced Concrete Columns," ACI Materials Journal, Vol. 88, No. 1, 1991.

86. Lie, T. T. and Chabot, M., "A Method to Predict the Fire Resistance of Circular Concrete-Filled Hollow Steel Columns," Journal of Fire Protection Engineering, Vol. 2, No. 4, 1990.

87. Lie, T. T., "Calculation of the Fire Resistance of Composite Concrete Floor and Roof Slabs," Fire Technology, Vol. 14, No. 1, 1978.

88. Bresler, B., Iding, R. and Nizamuddin, Z., FIRES-T3: A Computer Program for the Fire Response of Structure-Thermal (Three-Dimensional Version), UCB FRG 77-15, University of California, Berkeley, NIST GCR 95-682, National Institute of Standards and Technology, 1996.

89. A User's Guide for HSLAB: HSLAB - A Program for One-Dimensional Heat Flow Problems, FOA report C20827, National Defence Research Institute, Sweden, 1990.

90. Lie, T. T., "A Procedure to Calculate the Fire Resistance of Structural Members," Fire and Materials, Vol. 8, No. 1, 1984.

91. Lie, T. T. and Irwin, R. J., Evaluation of the Fire Resistance of Reinforced Concrete Columns with Rectangular Cross Sections, Internal Report No. 601, Institute for Research in Construction, National Research Council of Canada, Ottawa, ON, 1990.

92. Lie, T. T., "Temperature Distributions in Fire-exposed Building Columns," Journal of Heat Transfer, Transactions of the ASME, Vol. 99, No. 1, 1977.

93. Nwosu, D., Kodur, V., Franssen, J. M. and Hum, J., User Manual for SAFIR: A Computer Program for Analysis of Structures at Elevated Temperature Conditions, Internal Report 782, National Research Council of Canada, Ottawa, ON, 1999.

94. White, R. H., Cramer, S. M. and Shrestha, D. K., Fire Endurance Model for a MetalPlate-Connected Wood Truss, Res. Pap. FPL-RP-522, USDA Forest Service, Forest Products Lab., 1993.

95. Lie, T. T., Lin, T. D., Allen, D. E. and Abrams, M. S., Fire Resistance of Reinforced Concrete Columns, DBR Paper No. 1167, NRCC 23065, Natioanl Research Council of Canada, Ottawa, ON, 1984.

96. Sterner, E. and Wickstrom, U., TASEF - Temperature Analysis of Structures Exposed to Fire - User's Manual., Swedish National Testing and Research Institute (SP), SP Report 1990:05, Boras, 1990.

97. Lie, T. T., "Calculation of the Fire Resistance of Composite Concrete Floor and Roof Slabs," Fire Technology, Vol. 14, No. 1, pp. 26-46.

98. Spearpoint, M., "Predicting the Temperatures of Steel Members in the Cardington Fire Tests Using the THELMA Finite Element Model," Fire Technology, Vol. 37, No. 2, 2001.

99. Wade, C. A. and Lovatt, A. J., User's guide to BRANZ TR8, Software for Calculating Fire Resistance of Concrete Beams and Floor Systems, Building Research Association of New Zealand.

100. Lie, T. T. and Almand, K. H., "A Method to Predict the Fire Resistance of Steel Building Columns," Engineering Journal, American Institute of Steel Construction, Inc., Vol. 27, No. 4, 1990. 
101. Heskestad, A. W., Jensen, G., Meland, O. and Torlen, E., “ALLSAFE: An Engineering Tool for Evacuation Safety Design," In: Proceedings of the Fire Safety by Design Conference, Vol. 3, CIB W14, UK, 1995.

102. Paulsen, T., Soma, H., Schneider, V., Wiklund, J. and Lovas, G., Evaluation of Simulation Models of Evacuation From Complex Spaces (ESECX), SINTEF Report STF75 A95020, 1995.

103. Kendik, E., "Determination of the Evacuation Time Pertinent to the Protected Area Factor in the Event of Total Evacuation of High-Rise Office Buildings via Staircases," Fire Safety Journal, Vol. 5, 1982, p. 223.

104. Ketchell, N., Cole, S., Webber, D. M., Marriott, C. A., Stephens, P. J., Brearley, I. R., Fraser, J., Doheny, J. and Smart, J., "The EGRESS Code for Human Movement and Behaviour in Emergency Evacuations," Engineering for Crowd Safety, Institution of Civil Engineers, London, 1993.

105. Klote, J. H. and Alvord, D. M., Routine for Analysis of the People Movement Time for Elevator Evacuation, NISTIR 4730, National Institute of Standards and Technology, 1992.

106. EVACNET4 User's Guide, http://www.ise.ufl.edu/kisko/files/evacnet/EVAC4UG.HTM

107. Takahashi, K., Tanaka, T. and Kose, S., "An Evacuation Model for the Use in Fire Safety Designing of Buildings," In: Proceedings of the 2nd International Symposium on Fire Safety Science; International Association for Fire Safety Science, 1988.

108. Fahy, R. F., "EXIT89 - An Evacuation Model for High-Rise Buildings - Model Description and Example Applications," In: Proceedings of the Fourth International Symposium, International Association for Fire Safety Science, 1994, pp. 657-668.

109. Personal communication with Michel Curtat, Centre Scientifique et Technique du Batiment, France, curtat@ cstb.fr.

110. Thompson, P. A. and Marchant, E. W., "A Computer Model for the Evacuation of Large Building Populations," Fire Safety Journal, Vol. 24, 1995, pp. 131-148.

111. Shestopal, V. O. and Grubits, S. J., "Evacuation Model for Merging Traffic Flows in Multi-room and Multi-storey Buildings," In: Proceedings of the 4th International Symposium on Fire Safety Science, IAFSS, 1994, pp. 625-632.

112. Quintiere, J. and McCaffrey, B., The Burning of Wood and Plastic Cribs in an Enclosure: Volume I, NBSIR 80-2054, National Bureau of Standards (now National Institute of Standards and Technology), 1980.

113. Hagglund, B., A Room Fire Simulation Model, Department of Defense, FAO Report 620501-D6, Stockholm, Sweden, 1983.

114. Wickstrom, U. and Goransson, U., "Flame Spread Predictions in Room/Corner Test Based on the Cone Calorimeter," In: Proceedings of the Interflam Conference, 1990.

115. Pape, R., Waterman, T., and Eichler, T.V., "Development of a Fire in a Room from Ignition to Full Room Involvement - RFIRES," NBS-GCR 81-301, National Bureau of Standards (now National Institute of Standards and Technology), 1981.

116. Dietenberger, M., Technical Reference and User's Guide for FAST/FFM Version 3, NIST-GCR-91-589, National Institute of Standards and Technology, 1991.

117. Zukoski, E. and Kubota, T., "Two-Layer Modeling of Smoke Movement in Building Fires," Fire and Materials, Vol. 4, 1980.

118. Janssens, M. L., An Introduction to Mathematical Fire Modeling, 2nd Edn., Technomic Publishing Company, Inc., 2000.

119. Joshi, A. A. and Pagni, P. J., Users' Guide to BREAK1, The Berkeley Algorithm for Breaking Window Glass in a Compartment Fire, NIST-GCR-91-596, National Institute of Standards and Technology, 1991.

120. Mowrer, F. W., Methods of Quantitative Fire Hazard Analysis, Electric Power Research Institute, EPRI TR-100443s, 1992. 
121. Personal communication with Dr. Frederick Mowrer, University of Maryland, Department of Fire Protection Engineering, College Park, Maryland,

fmowrer@eng. umd.edu.

122. Personal communication with Peter Simenko, SimCo Consulting, SimCo@alphalink.com.au.

123. Sleights, J. E., Sprink 1.0: A Sprinkler Response Computer Program for Warehouse Storage Fires, Masters Thesis, Worcester Polytechnic Institute, 1993.

124. Haynes, E. K., Development of WPI/FIRE 3.0: A Multiroom Model, Masters Thesis, Worcester Polytechnic Institute, 1994.

125. http://www.tunnelfire.com

126. Personal communication with Dr. Raymond Connolly, Fire and Risk Solutions Ltd., Connollyrj@eircom.net.

127. Personal communication with Dr. Zhao Bin, Centre Technique Industriel de la Construction Métallique, France, binzhao@cticm.com.

128. Personal communication with Geir Berge, Petrell AS, geir.berge@petrell.no.

129. Cappuccio, J. A., Jones, W. W. and Forney, G. P., "FireCAD Development for Hazard Analysis," In: Proceedings of the 2nd International Conference on Fire Research and Engineering (ICFRE2), National Institute of Standards and Technology and SFPE, Gaithersburg, MD, August, 1997.

130. Personal communication with Dr. Nicole Hoffman, Mott McDonald Limited, UK, nh2@mm-croy.mottmac.com.

131. Personal communication with Cliff Barnett, Macdonald Barnett Partners, Ltd., New Zealand, cliff@macbar.co.nz.

132. Personal communication with Cajot Louis-Guy, ProfilARBED Research, Luxembourg, lg.cajot@profilarbed.lu.

133. Fluent/UNS and Rampant 4.2 User's Guide, 1st Edn., 1997.

134. Deal, S., Technical Reference Guide for FPEtool Version 3.2, NISTIR 5486-1, National Institute of Standards and Technology, 1995.

135. Babrauskas, V., "Letter to the Editor," Journal of Fire Protection Engineering, Vol. 5, No. 1, 1993, p. 35.

136. Baum, H.R. and McGrattan, K.B., "Simulation of Oil Tank Fires," In: Proceedings of the Interflam '99 Conference, Vol. 2, Edinburgh, Scotland, 1999. 